\title{
Exploring attitudes to NATO in Republika Srpska
}

Ron Roberts ${ }^{1}$, Majda Halilović ${ }^{2}$, Edina Becirević ${ }^{2} \&$ Christopher J. Hewer ${ }^{1}$

1. Department of Psychology

Kingston University

Penrhyn Road

Kingston

Surrey

KT1 2EE

United Kingdom

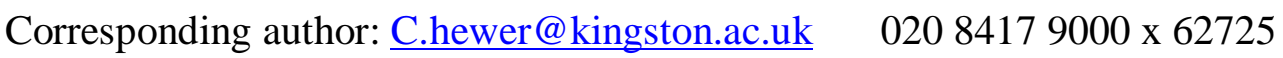

r.a.roberts@kingston.ac.uk 02084179000 x 67007

2. Atlantic Initiative

Despićeva No. 3.

Sarajevo, 71000

Bosnia \& Herzegovina

The Atlantic Initiative (AI) is a non-profit and non-governmental organization, established in Sarajevo in 2009 by a group of university professors, lecturers, and journalists who share common concerns for the future of Bosnia and Herzegovina, particularly related to the slow pace of its accession to NATO and the European Union. 


\begin{abstract}
The role of NATO in the maintenance of regional security was assessed from a random sample of 1,000 residents in the Serbian entity Republika Srpska (RS) - part of Bosnia and Herzegovina - in the fall of 2011. Attitudes to NATO were largely divided along ethnic lines. Evidence of positive attitudes towards NATO was mostly found among (i) non-Serbs (71\%) compared to Serbs (18\%), (ii) women and (iii) respondents over 65 years. Specific features underpinning these responses were analysed and modelled, which included consequences of NATO membership in the domain of security, economics, international reputation and international relations. A main effects general linear model was able to predict $25.7 \%$ of the variance. Ethnicity, age group, level of education, degree of trust in politicians, understanding the role and purpose of NATO and the importance attached to reaching a common understanding of the past were significant predictors. Logistic regression models of a pro or anti NATO stance predicted considerably higher variation and showed that the importance attached to reaching a common understanding of the past is predicated, not on ethnicity per se, but on general responses to NATO and whether Serbia would benefit from NATO membership. The implications of these findings for political stability and reconciliation within the region are discussed.
\end{abstract}

\title{
Word Count: 6,665
}

Key Words: Attitudes, Bosnia and Herzegovina, Republika Srpska, NATO, memory

Within any national group, the way in which institutions, ethnic groups and historical events are understood creates a version of political reality that either inhibits or facilitates the development of adaptive social and international relations. The Bosnian state $(\mathrm{BiH})$, which consists of two entities, The Federation of Bosnia-Herzegovina (FBiH), formed from the Muslim-Croat alliance, and the Serb controlled Republika Srpska (RS), currently has to contend with the social and economic difficulties that have ensued as a consequence of the conflict with Serbia between 1992 and 1995. In addition, relations between various Yugoslav successor states stand to be profoundly affected by current and future relations with two major international institutions: The North Atlantic Treaty Organisation (NATO) and the European Union (EU).

NATO involvement in Bosnia began during the war of 1992-1995 following the break-up of the former Yugoslavia after having previously considered the Balkans "out of area" (Stokes, 2009, p. 97) for military measures. Ethnic cleansing and systematic violence directed toward the civilian population, and notably the genocide in Eastern Bosnia (Brunborg, Lyngstad \& Urdal, 2003; Bećirević, 2009, 2010, 2014), eventually forced the hand of the Clinton administration in the US. Despite initial resistance in European and Russian quarters, the failed strategy premised on humanitarian intervention (Jackson \& Sørensen, 2007) was brought to a close. In March 1993, UN 
Security Council Resolution 816 (Klemenčič, 2009) was authorised and a no-fly zone over the country was implemented a month later. Subsequent to this, Security Council Resolutions 819 and 824 authorised safe area in Srebrenica, Sarajevo, Žepa, Goradže, Tuzla and Bihać. However, the lack of clarity regarding the way these safe areas were to be protected was exploited by the Serbs. The result was genocide at Srebrenica, which set in motion a chain of events leading to a forthright NATO response against Bosnian Serb positions in September 1995.

The Dayton Peace Agreement, which formally ended the Bosnian war, was a direct consequence of NATO action alongside a joint Croat-Bosniak offensive, actions which substantially changed the situation on the ground. Under the agreement, the Bosnian State - Bosnia and Herzegovina (BiH) was to comprise two entities: The Federation of Bosnia Herzegovina $(\mathrm{FBiH})$ formed from the Muslim-Croat alliance forged during the war, and the Serb controlled Republika Srpska (RS). Upon conclusion of the accord, NATO immediately set up an Implementation Force (IFOR), a one-year peacekeeping mission, mandated to oversee the military annexes of the General Framework Agreement ${ }^{1}$. IFOR also effectively relieved the UN peacekeeping force (UNPROFOR), which had been present in the country since 1992 (Silber \& Little, 1997). In April 2010, NATO agreed to grant a Membership Action Plan (MAP) to Bosnia, which is the penultimate step in a process that leads to full NATO membership. The MAP is a "NATO programme of advice, assistance and practical support tailored to the individual needs of countries wishing to join the Alliance." ${ }^{2}$ However, before Bosnia can begin the process, it is a NATO requirement that all military property in the country be registered with the Bosnian state (Šolaya, 2010). By 2011, one third of sites considered usable for military purposes were ready for state ownership. However, there have been complications with the remaining sites as "a number of buildings from the list of 69 sites visited are outdated and require significant investment to put them in order". ${ }^{3}$ Only once this has been completed, can Bosnia join the MAP programme. The integration of Bosnia and Herzegovina $(\mathrm{BiH})$ within NATO and within the European Union is considered of paramount importance for the future of the country (Beaumont, 2009) and the wider stability of the Western Balkans (see Radeva, 2010, Attila Hoare, 2010).

These developments, however, create a degree of tension in the region. Those living in RS, who are ethnically and culturally linked to Serbia, for the most part, look to Russia as their traditional ally, and because NATO is the principal military tool of the West, proxy Cold War political dynamics rekindle longstanding political alliances and psychological allegiances. There is also continuing resentment among Serbs over NATO's military action that brought an end to the Bosnian war and to their intervention in Kosovo four years later. Although the Cold War ended in 1991 and the Bosnian war in 1995, the past continues to resonate through the generations. Furthermore, to add to the political and psychological complexity of the situation, Serbia now openly seeks membership of the

\footnotetext{
${ }^{1}$ The General Framework Agreement (The Dayton Accords) for peace in Bosnia and Herzegovina can be found at http://www.ohr.int/dpa/default.asp?content id=380. For military aspects of the peace settlement, see Annex IA.

${ }^{2}$ http://www.nato.int/cps/en/natolive/topics_49127.htm

${ }^{3}$ http://www.nato.int/cps/en/natolive/topics_49127.htm
} 
European Union, which moves political and economic interests in the region westwards. For many living in Republika Srpska, the continual shift towards and away from western institutions may well create a dissonant psychological state. This is the point at which social memory, political beliefs and identity converge to create a complex, shifting and, at times, a competing sense of political reality for many in the region. While political stability is the objective of all parties, views on NATO in BiH are highly polarised. Since 2006, the State building that characterised the immediate post-war period has come to a halt. In 2008, former High Representative Paddy Ashdown, and Dayton negotiator Richard Holbrooke called for concerted international action, describing the country as "sleepwalk(ing) into another crisis" and in "real danger of collapse" (Ashdown \& Holbrooke, 2008). Such action has not been forthcoming and, since the inconclusive general election in October 2010, there has been a marked deterioration in political stability (Azinović, Bassuener \& Weber, 2011). Even Bosnian Serb (RS) Prime Minister Milorad Dodik repeatedly called for the dissolution of the Bosnian state. In the midst of this continuing crisis and increasing calls for international actors to return to the political stage in Bosnia, the future role of NATO may be of considerable importance.

\section{Rationale}

While there is recognition of the need for rapprochement with Serbia within FBiH (Roberts, Becirevic \& Paul, 2011), little is known about the representations of NATO among those living in RS. Therefore, this exploratory study seeks to explore attitudes to NATO within Republica Srpska (RS), which includes an evaluation of prospective BiH NATO membership. Understanding the underlying structure of these representations within RS (estimated population >3million) would provide an indication of the current state of political cohesion and the likelihood of achieving consensus in the region.

\section{Method}

\section{Social representations of NATO}

Historically, academic interest in NATO has largely been concerned with three broad issues, USSoviet/Russian relationships during and following the Cold War (e.g. Forsberg, 2005), the perceived legitimacy of specific NATO actions and the question of NATO enlargement encompassing a number of post-communist states. The present study is not the first to assess representations of NATO in the context of the history and politics of the Western Balkans. For example, Atanasović (2007) tracked attitudes to NATO in Serbia in a series of surveys between June 2003 and April 2005. Two years earlier, Hanze (2001) investigated attitudes and feelings in a small sample of German students towards NATO's military intervention during the course of the war in Kosovo and Kovács (2005) examined public opinion in Hungary on NATO membership over the same period. This type of 
attitudinal research can provide a foundation for gauging public opinion. Whatever method is selected, the objective at the initial stage is to accumulate relevant foundational knowledge, which means that the study is often exploratory rather than inferential, i.e. it seeks to identify areas worthy of more detailed investigation at some later date. In this respect, given the size and nature of the sample $(N=950)$, this study provides a substantial foundational analysis from which to proceed.

\section{Design and sample}

The attempt to survey a representative sample in either Bosnian entity faces particular challenges not encountered in other European populations. At the time of the study Bosnia was the only country in the region, following the dissolution of the former Yugoslavia, not to have conducted a census (Azinović, Bassuener \& Weber, 2011). The last published census of the population of Bosnia was taken in 1991, which predates the large population upheavals created by the 1992-1995 war. A census was undertaken in 2013, though final results (as of June 2015) have yet to be published. Notwithstanding these obstacles, a telephone survey was carried out in RS, and to counter the absence of a viable electoral roll, a random sample of telephone subscribers was obtained from the most recently available directory. This methodology has two advantages: (i) there is no need to employ (geographical) cluster sampling and (ii) potential respondents from remote areas can also be included (Groves et al, 2001, Nicolaas, 2004). Information from The Republika Srpska Institute of Statistics (2009, p. 20) indicated that $85.2 \%$ of urban households and $61.7 \%$ of rural/semi urban households have a telephone. (Figures obtained from a master panel survey involving a micro-census of municipalities). The State Agency for Statistics for BiH (2001, p. 15) also acknowledged that the precision of many of the population estimates is "equivalent to a true random sample of just 1000 households." Therefore, while we accept that estimates derived from a telephone sample will be subject to bias, this should not be appreciably higher than existing data sets. Initially, a target set of 1,000 subscribers was produced by means of a table of random numbers generated by the random number function in SPSS16. The numbers were based on the size of the RS telephone directory and the number of subscribers listed on each page. In the process of generating the numbers no duplicates were permitted. In the event of non-response, interviewers were instructed to move to the next available number in the list. This systematic protocol eventually produced a sample of 950 respondents.

\section{Questionnaire items}

The questionnaire contained a variety of demographic measures (age last birthday, gender, ethnicity, employment status, annual income, highest level of education) and political party membership. Age was coded into six distinct groups; 18-24, 25-34, 35-44, 45-54, 55-64 and 65 and above. While previous studies by Hanze (2001) and Atanasović (2007) utilised single item measures to assess 
attitudes to NATO, which is standard practice in Western research on foreign policy attitudes (e.g. Zeigler, 1987), this study employed a more comprehensive inventory of items. This has the advantage of reducing measurement error (Ansolabehere, Rodden \& Snyder, 2006) and is more suited to revealing the structure of stable underlying preferences. It also allows us to understand and predict socio-economic and cultural correlates of any particular stance taken towards NATO as well as locating its source or origin.

\section{Quantitative measures}

A number of items addressed respondents' views about the consequences of NATO membership in the domains of security, economics, international relations and international reputation. These questions all pertained either to the Bosnian state $(\mathrm{BiH})$ or the Serbian entity (RS) within it. General questions were also posed about the role, purpose and future development of NATO. A further series of items concerned the political informational environment in RS; the degree of trust in politicians, whether people consider that they receive sufficient and objective information about NATO; and the degree to which respondents considered themselves well informed about politics. With the exception of one item concerning the level of understanding of the role and purpose of NATO (rated on a fourpoint scale), participants were invited to state their level of agreement with these statements on a fivepoint scale (strongly disagree to strongly agree). One further item (rated on a four-point scale) concerned the importance attached to all people in Bosnia and Herzegovina $(\mathrm{BiH})$ coming to a common understanding of the recent past (i.e. the 1992-1995 war), specifically, that the media in RS and the Federation of $\mathrm{BiH}$ disseminate the same historical narrative and that children in schools learn a common account of history. Two additional items were included as a means of assessing the construct validity of the attitude scale. The first asked participants to give their view of NATO (from negative to positive) on a four-point scale. The second item asked participants to indicate their level of agreement with the statement "Serbia would benefit from becoming a member of the NATO alliance". Statements about NATO were worded in both favourable (e.g. NATO membership will contribute to good relations with other countries in the region) and unfavourable terms (e.g. NATO expansion is a bad thing) to minimise response bias. In addition, presentation of response options (strongly agree to strongly disagree) was counterbalanced.

\section{Qualitative measures}

To supplement the quantitative data, there were several open-ended questions on the questionnaire. These addressed general impressions of NATO, sources of information that have influenced impressions of NATO, the positive or negative rationale for NATO membership for Bosnia (FBiH), and the quality of political leadership within the state. 


\section{Procedure}

Six students from different universities in Republika Srpska conducted telephone interviews during September and October 2011. At the beginning of this project, the Atlantic Initiative provided intensive training in research methods and methodology and the students had the opportunity to practice telephone interviewing. During the period of fieldwork, interviewers received continuous supervision by the Atlantic Initiative. Data from the interviews were subsequently coded and entered into SPSS. The responses from open-ended questions were entered as string variables for subsequent thematic analysis. In addition to the survey, and to assist in its validation (see Carpini \& Keeter, 1993) a series of focus groups were held in Bijeljina, Milici, Prijedor, Banja Luka and Trebinje. The focus groups addressed some of the same questions found in the survey and additional questions concerning the perception of NATO and, in particular, images and associations prompted by NATO as an organisation.

\section{Analysis}

Quantitative: All analyses were conducted through SPSS (v16).

1. Frequency counts of the responses to closed questions were generated

2. Because of the number of response alternatives (Streiner \& Norman, 1989), Cronbach's $\alpha$ was used as a measure of internal consistency for items on the NATO scale. This was compared with principal components analysis of the same items.

3. On condition of meeting a satisfactory criterion ( $\alpha \geq 0.70$; Nunnally, 1978), the concurrent, discriminant and predictive validity of the scale was explored through correlational methods, the t-test and general linear model.

4. Should the scale exhibit satisfactory properties, analysis will be undertaken to determine predictors of favourable representations of NATO. This analysis will comprise both general linear modelling and use of artificial neural networks (Multilayer Perceptron Analysis).

\section{Results}

\section{Sample characteristics}

A majority of the survey respondents were male ( $n=596,63.1 \%$ cf. $n=348$ female, $36.9 \%)$. The mean age of the sample was 41.08 years $(S D=17.31)$ with a range from 18 to 84 years. The ethnic composition of the sample was similar to that reported in 1996 in the UNHCR census (Republika 
Srpska Institute of Statistics, 2009) and comprises Serbs as the largest group ( $n=895,94.7 \%)$, followed by Bosniaks $(n=27,2.9 \%)$ and Croats $(n=4,0.4 \%)$. Other categories of ethnic identification were given as Mixed $(n=9,0.9 \%)$, National Minority $(n=1,0.1 \%)$ and Other $(n=9$, $1 \%)$. Small numbers of non-Serbs in subsequent statistical analyses have been grouped together. Data on employment status was missing from 61 people (6.4\%). Of those providing data, $361(40.6 \%$, $44.1 \%$ males, $34.8 \%)$ were employed and 528 (59.4\%) were not. Almost one in six $(n=152,16 \%)$ described themselves as retired and, of these, 124 were not working. When these are subtracted from the 'not working' category, a revised estimate for the eligible population results, i.e. $47.2 \%(361 / 765)$ employed and 52.8\% (404/765) unemployed. These raw figures for employment are close to those provided by official sources in RS (Republika Srpska Institute of Statistics, 2009), which estimated the employment rate in 2008 at $37.3 \%$ (48\% for males and $27.2 \%$ for females) - both are considerably greater than the figure of $10 \%$ reported in the years after the war (Ramet, 2005, p. 189). Among those currently working, mean reported monthly income was 718.30 Bosnian marks $(S D=382.53$ ), which is somewhat lower than official sources. Over half the sample $(61.5 \%)$ was educated to secondary school level with a further $30.4 \%$ educated to college or university level. Just under one quarter $(n=$ $222,23.4 \%$ ) reported membership of a political party.

\section{Item analysis}

Tables.1a and $1 \mathrm{~b}$ below present the frequencies by which the principal questionnaire items were endorsed. These are also shown broken down by ethnicity.

\section{Insert Tables 1a and 1b}

The table shows that a majority of the statements exhibited marked ethnic differences, not only with respect to the benefits offered by NATO in the domains of security, economics and political stability, but also in relation to its purpose and the consequences of its actions for the region. Although Serbs in Republica Srpska are less favourable to NATO, there is nonetheless a sizeable minority who consider NATO favourably. Between one in six and one in seven Serbs claim that NATO membership would be a good thing for Republica Srpska (14.8\%), that it would enhance security in RS (15.7\%) and bring economic benefits (16\%). Furthermore, over one in five (21.2\%) believe it would contribute to good relations with other countries in the region. In addition, almost a quarter (23.9\%) claim that it would enhance the international reputation of RS (23.9\%) and more than one in three (36.5\%) see NATO membership as enhancing the Bosnian State's chances for EU accession. Other striking features of the data across ethnic lines are (i) the widespread distrust of politicians (80.5\% Serbs cf. 92\% Non-Serbs), and (ii) that people in Republica Srpska do not receive objective information about NATO (Serbs $53.5 \%$ cf. $56 \%$ Non-Serbs). In addition, less than half of the respondents in each group (Serbs $40.7 \%$ cf. non-Serbs 44\%) consider themselves well informed about international politics and large 
majorities of both Serbs (63.8\%) and non-Serbs (86\%) consider it either 'important' or 'very important' that all people in Bosnia reach a common understanding of the recent past.

\section{Attitudes to NATO: Scale construction}

The first twelve of these statements were assessed for their ability to form a composite scale measuring overall attitude toward NATO. The internal consistency of these was high (Cronbach's $\alpha$ $=0.93$ ) with a mean item-total correlation of 0.73 (range $0.49-0.84$ ). Factor analysis of the same variables produced a single factor accounting for $61 \%$ of the variance. This factor correlated 0.99 with the scale score derived from simple summation, thereby indicating that computation of the scale score could proceed from a simple summation of items rather than using regression weights. The composite variable formed from summing the individual items produced scores ranging from a minimum of 12 to a maximum of $57(M=29.29, S D=9.63)$. This compares to a maximum theoretical range from 12 to 60 where 12 equals the most unfavourable possible score and 60 equals the maximum possible favourable score. Scores above 36 can be considered to denote a favourable attitude to NATO. Just under a quarter of respondents $(n=202,22.4 \%)$ indicated a favourable attitude by this criterion. Scores below the theoretical midpoint (36) can be considered to denote an unfavourable attitude to NATO. Just under three-quarters $(n=665,73.8 \%)$ scored in this range. The distribution of scores is illustrated in Figure.1, which is a good approximation to a normal distribution $(M=29.3, S D=9.64)$.

\section{Insert Figure 1}

Scale validity

Content validity

We would argue that this criterion is easily met as the scale items pertain to a broad range of aspects and possible consequences of NATO membership i.e. the scale items are representative of the wide range of circumstances in which specific attitudes are generated (Streiner \& Norman, 1989).

\section{Discriminant validity}

Examination of the validity of the scale was conducted first of all by examining the correlates of the attitudinal scale and its ability to discriminate between different groups.

\section{Variation in Attitudes to NATO by demographic variables}

Analysis of the data suggested differences in scale scores by a number of variables; gender, age, ethnicity and level of education. These differences are described below. 


\section{Gender}

Females had significantly more favourable attitudes to NATO than males (30.87 cf. $28.47 ; t$ (895) 3.6, $\mathrm{p}<.005)$.

Age

A general linear model showed significant differences in attitudes to NATO by age $(F(5,885)=3.72$, $p=.002$ ) with significantly more favourable attitudes present in older respondents (65 years of age and older). See Figure.2 below.

\section{Insert Figure 2}

Scheffe's post hoc test showed that NATO scale scores were significantly or marginally significantly higher in this age group compared to 18-24 year olds $(p=.068), 35-44$ year olds $(p=.065), 45-54$ year olds $(p=.018)$ and 55-64 year olds $(p=.017)$. Though higher, scores from those above 65 were not significantly different to those from 25-34 year olds $(p=.15)$.

\section{Ethnicity}

Serb respondents were found to hold a significantly more negative attitude to NATO (28.74 cf. 40.77) compared to Non-Serbs $(t(895)=8.39, p<.0005)($ see Figure 3$)$.

\section{Insert Figure 3}

\section{Level of education}

A general linear model showed no significant differences in attitudes to NATO by level of education $(F(4,883)=1.75, p=.14)$. However the most favourable attitudes were evident amongst the least educated (Primary; 31.02, $S D=9.42$ ) followed by the most educated (University; 30.39, $S D=9.68$ ). Those with primary education had scores that were marginally significantly higher $(F(1,886)=3.26, p$ $=0.07)$ than all other groups.

Variation in responses to NATO by other political views

Analysis of the items assessing other political views and attitudes yielded a variety of significant relationships with NATO scale scores. These measures included degree of trust in politicians, understanding the role and purpose of NATO, being well informed about politics in RS and being well-informed about international politics, degree of importance people attached to the people of Bosnia reaching a common understanding of the events of the recent past. Details of these relationships are outlined below and provide substantial further evidence of the scale's validity. 
Low levels of trust are related to more favourable attitudes $(r=0.15, p<.0005, n=900)$.

\section{Understanding the role and purpose of NATO}

This was inversely related to NATO attitude $(r=-0.24, p<.0005)$ with those reporting greater understanding having a less favourable attitude.

Being well informed about politics in RS $(r=-0.23, \mathrm{p}<.0005, n=900)$ and being well informed about international politics $(r=-0.06, p=.056, n=899)$ negatively correlated with a favourable NATO attitude.

Degree of importance people attached to the people of BiH reaching a common understanding of the events of the recent past

Greater importance correlated with a more favourable attitude $(r=0.32, p<.0005, n=882)$.

A general linear model yielded no significant interactions between gender, ethnicity and age (gender $\mathrm{x}$ age, $F(5,861)=0.24, p=0.946$; gender $\mathrm{x}$ ethnicity, $F(1,861)=0.33, p=.57$; age $\mathrm{x}$ ethnicity, $F(5$, $861)=0.30, p=.91$; gender $\mathrm{x}$ age $\mathrm{x}$ ethnicity, $F(3,861)=1.01, p=.39)$. No significant differences in attitude to NATO were found by employment status $(F(1,843)=0.39, p=.53)$, income $(r=-0.06, n$ $=384, p=.23)$ or membership of a political party $(F(1,897)=0.13, p=.71)$.

\section{Construct validity}

As indicated earlier a single item measure in which participants were asked to give their view of NATO (from negative to positive) on a four-point scale was included in the survey. This provides a means for assessing construct/concurrent validity. Validation of the 12 item scale was supported by high significant correlation with the single item measure $(r=0.71, p<.0005, n=897)$. Recoding of the single item into a binary variable (positive $\mathrm{v}$ not positive) enabled the single item measure to be compared with the scaled variable for its sensitivity and specificity to detect a positive or negative attitude to NATO. Of those designated as having a positive attitude by the scale score only $53 \%$ were correctly identified by the single item (sensitivity $=0.53$ ) whilst $98 \%$ of those designated as having a negative attitude (specificity $=0.98$ ) were correctly identified. As the scale was constructed from items pertaining to the Bosnian state and the Serbian entity within it, a further test of construct validity comes from correlating the scale with the item which is addressed to its principal neighbouring state, i.e. whether "Serbia would benefit from becoming a member of the NATO alliance". As predicted, there was a high correlation between these items $(r=0.81, n=898, p<$ $.0005)$. 


\section{Modelling responses}

A main effects general linear model using the variables identified above was able to predict $25.7 \%$ of the variance in attitude to NATO $(F(13,836)=23.63, p<.0005)$. In this model, ethnicity (partial $\eta^{2}=$ $.058, p<.0005$ ), age group (partial $\eta^{2}=.02, p=.006$ ), education (partial $\eta^{2}=.007, p=.02$ ), degree of trust in politicians (partial $\eta^{2}=.029, p<.0005$ ), understanding the role and purpose of NATO (partial $\left.\eta^{2}=.025, p<.0005\right)$, and importance attached to reaching a common understanding of the past (partial $\eta^{2}=.089, p<.0005$ - the strongest predictor) were all highly significant. In addition, gender (partial $\eta^{2}=.003, p=.09$ ) and being well informed about politics in RS (partial $\eta^{2}=.004, p=.08$ ) were marginally significant. Being well informed about international politics was not significantly related $(p=.22)$.

By using the same predictors in an artificial neural network (Multi-Layer Perceptron) over the course of 110 simulations, the predictive utility of the model marginally increased, explaining on average $28.2 \%$ (range $20.6 \%$ to $32.2 \%$ ) of the variance in NATO scale scores (see Figures 4 and 5. below). Ethnicity and importance attached to reaching a common understanding of the past were again the most important explanatory variables - the weightings attached to these explained $62 \%$ of the variability in the explained R-Square, though overall the weightings given to these did not differ significantly $(t(109)=.85, p=.40)$.

\section{Insert Figures 4 and 5}

In addition to modelling NATO attitudinal variance by linear regression, we also looked for a criterion of demarcation between those who are favourable to NATO from those who are not. To model NATO scores in terms of binary outcomes entails the use of logistic regression. Given the marked ethnic differences in the frequencies endorsing the various statements, it was decided to conduct the logistic regression analysis for Serbs and Non-Serbs separately. The analyses are described below.

\section{Predictors of favourable responses to NATO membership amongst Serbs}

A distinct minority of Serbs $(n=171,18 \%)$ exhibited a favourable attitude to NATO), the question then is what distinguishes those who are favourable from those who are not? The same variables used to model the overall NATO scores (with the exception of ethnicity) were used to model favourability to NATO scores. A hierarchical logistic regression was used with age group, gender and education entered in the first step (all as categorical variables). In step two, degree of trust in politicians, 
understanding the role and purpose of NATO, being well informed about politics in RS, being wellinformed about international politics, and degree of importance people attached to the people of Bosnia reaching a common understanding of the recent past were entered. In a final step, the item "Serbia would benefit from becoming a member of the NATO alliance" was added. Results are shown in Table.2.

\section{Insert Table 2a}

The final model $\left(\chi^{2}(17)=412.65, \mathrm{p}<.0005\right.$; Hosmer $\&$ Lemeshow $\left.\chi^{2}(8)=5.99, p=.65\right)$ explained between $40 \%$ (Cox \& Snell) and 65\% (Nagelkerke) of the variance and correctly classified $89.1 \%$ of the Serb participants as Pro/Anti NATO. Three variables contributed significantly to distinguishing between those favourable to NATO and those who were not. These variables were: understanding the role and purpose of NATO $(p=.04)$, importance attached to reaching a common understanding of the past $(p<.0005)$ and whether Serbia would benefit from NATO membership $(\mathrm{p}<.0005)$.

\section{Predicting favourable responses to NATO amongst Non-Serbs}

Among Non-Serbs, a majority had favourable attitudes to NATO $(n=31 / 44=70.45 \%)$. Following Peduzzi et al's (1996) guidelines for calculating sample sizes for logistic regression, a model with eight predictors would require a sample size of $10 \times 8 /(1-0.7045)$, which is equal to 270 . Even the less stringent criterion suggested by Kleinbaum, Kupper and Mullet (1988), whereby the number of covariates are multiplied by 10 , would necessitate a sample size almost double the number of nonSerbs in the present study. Vittinghoff and McCulloch (2006), however, acknowledge that it may be permissible for logistic models to violate this rule of thumb without undue problems when it is necessary to control for confounding variables, and when the ratio of cases to variables is between five and ten. Consequently, we elected to construct a five variable model for non-Serbs; gender and age are included as controls (entered in step one), with the remaining three variables (those suggested by the model with Serb participants; understanding the role and purpose of NATO, attitude to the recent past and whether Serbia would benefit from NATO membership) entered subsequently. This compromise should avoid the risk of over fitting the data - a potential risk of logistic models with low sample sizes - while giving an indication of the predictive capacity of the model among non-Serbs. Results of this hierarchical logistic regression are presented below in Table $2 \mathrm{~b}$.

\section{Insert Table 2b}

This model also fitted the data well $\chi^{2}(9)=22.01, p<.0005$; Hosmer $\&$ Lemeshow $\chi^{2}(8)=5.99, p=$ .65 ) and explained between $41.5 \%$ (Cox \& Snell) and 60.4\% (Nagelkerke) of the variance. It correctly 
classified $80.5 \%$ of the non-Serb participants as pro/anti NATO. Whether Serbia would benefit from becoming a member of the NATO alliance was the only variable to approach statistical significance ( $p$ $=.08)$. However, given the vastly lower power in this sub-sample compared to the first means that the absence of significance must be treated with caution. For example, while importance to understanding the past was a highly significant predictor of NATO favourability when modelled among Serbs, and was not significant in the analysis of non-Serbs, it should be noted that the raw correlation between this item and the dichotomous variable of NATO favourability was identical (0.23) in both Serb and Non-Serb populations. Thus, it is the overall effect size that should concern us more than significance per se. In the case of the variable relating to understanding the role and purpose of NATO, however, the situation is different. The raw correlations with NATO favourability (- 0.15 in the Serbian sample and +0.15 amongst the non-Serbs) do suggest that the relationship between the predictor and NATO favourability may be different across ethnic lines, i.e. that greater reported understanding of NATO among Serbs is related to a less favourable attitude, while among non-Serbs, the opposite is the case.

Taken together, these analyses suggest, first of all, that whether one is favourable to NATO can be predicted reasonably well in both the Serb and Non-Serb population. Secondly, a strong predictor amongst both Serbs and non-Serbs is the degree to which Serbia would be considered to benefit from becoming a member of the NATO alliance. Finally, although the lower power available in the analysis of non-Serbs must be treated with caution, the analyses raise the interesting possibility that the predictors operating within each group may do so differently. To understand these possible differences, further analysis of the meanings attributed to NATO and how these may be related to the construction of the past, was required. This data was obtained from the focus groups held across the region.

\section{NATO and political attitudes to the past: Focus groups and survey data}

What is evident from the data is that the public view of NATO is ethnically polarised. This is likely because the history of NATO in the region is itself ethnically polarised. NATO actions against Bosnian Serb positions arguably played a major role in bringing the war in Bosnia to a close and are a likely influence in the largely positive views expressed by Non-Serbs. On the other hand, many Serbs in RS see the Serb population as the target of NATO actions in Eastern Bosnia (later to become the Serb entity in Bosnia) and later in Belgrade against the Milošević regime during the war in Kosovo. Not surprisingly then, when participants in the focus groups were asked what formed their views towards NATO, an overwhelming majority cited NATO intervention in Bosnia and Serbia. Several participants for example remarked that they associate NATO with peace because "after all, NATO stopped the war in Bosnia”, while on the other hand, comments by some Serbs reflect an antipathy toward NATO. 
They bombed us, and our countrymen, and purposefully turned against our people. Even though NATO membership can be correct politically, it is not correct towards victims.

I dont know why, I simply don't know why, but I just don't like NATO.

A number of participants were able to rationalise their objections to NATO membership in terms of broader regional and global politics:

I don't think we need to rush to join NATO because of the possible problems between NATO and Russia...we need to balance between both sides.

In addition to the negative emotions towards NATO stemming from past NATO intervention in Bosnia (1995) and Serbia (1999), recent NATO intervention in Libya was frequently mentioned as a basis for unfavourable views towards NATO. Furthermore, a number of focus group participants expressed scepticism of the values that NATO promotes, such as democracy and human rights.

To me NATO is one big organisation for destroying the world's regimes. When they do not like a regime somewhere they destroy it. They destroyed Libya and it was such a rich country.

Overall, the focus groups provided an enriched understanding of the divided representations of NATO. This was illustrated in an exercise in which participants were asked to rate the extent to which they associate words such as peace, security, defence, freedom, human rights, democracy, effectiveness and modernity with NATO. Approximately half of the participants associated security and modernity with NATO, and some associated peace with NATO because of its role in bringing an end to the war in Bosnia, but no other words were linked to NATO.

In the final analysis, we modelled (via hierarchic logistic regression) the importance attached to past understanding (some/none) in terms of (step one) ethnicity (Serb/NonSerb), (step two) whether Serbia would benefit from future NATO membership (Yes/No, not sure) and (step three) attitude to NATO (positive/negative). Initial analysis showed that, in comparison to Serbs, non-Serbs were almost three times more likely to attach importance to reaching a common understanding of the past $(p=.013, \operatorname{Exp}(B)=2.84 ; 95 \% \mathrm{CI}=1.25-6.48)$. However, with the addition at step two of "whether Serbia would benefit from NATO membership' ( $p<.0005$, Exp $(B)=2.43 ; 95 \%$ CI $=1.57-3.80$ ), the odds ratio for ethnicity was no longer significantly different from zero $(p=.12, \operatorname{Exp}(\mathrm{B})=1.96$; $95 \% \mathrm{CI}=0.84-4.59) . \quad$ Finally, with the addition of attitude to NATO on the final step $(p<.0005$, $\operatorname{Exp}(\mathrm{B})=3.27 ; 95 \% \mathrm{CI}=1.96-5.43)$ neither ethnicity $(p=0.33 ; \operatorname{Exp}(\mathrm{B})=1.55 ; 95 \%$ CI $0.65-$ 3.70) nor whether Serbia would benefit from NATO membership $(p=.61, \operatorname{Exp}(\mathrm{B})=1.15 ; 95 \% \mathrm{CI}=$ $0.67-1.99)$ was significantly related to the importance attached to past understanding. 


\section{Discussion}

Although these findings pre-date the current conflict in the Ukraine, which may have further polarised, affected or influenced existing allegiances in the region, it does not diminish their relevance. Indeed, the Ukraine conflict simply highlights the importance of understanding political attitudes and allegiances in any region where there are contentious issues.

The main finding of the study points to ethnically polarised attitudes towards the NATO alliance with much more favourable responses observed in the non-Serb population (71\%) within Republika Srpska compared to $18 \%$ of Serbs. However, we need to ask important questions about the source and complex nature of these attitudes. While these findings reflect a longstanding mistrust of NATO among Serbs found in previous work, the position is not straightforward. For example, Atanasovićs (2007) study of attitudes in Serbia showed that only $4.3 \%$ would trust the alliance, while almost 30\% were prepared to support Serbia joining NATO.

However, what is of particular interest in this study is that a sizeable minority of Serbs in RS almost one in five - had a positive attitude to NATO despite the negative influence of recent political and military events. Indeed, Atanasović noted a slow rise in the popularity of NATO over the course of his study. So while it is not possible to draw conclusions about time trends from a single crosssectional study, it could be of considerable importance to replicate this study in order to monitor future shifts and trends within RS and Bosnia in general. One of the key factors underlying an overall positive stance, among both Serbs and non-Serbs, was an image of Serbia integrated within NATO benefitting from membership. Serbs who see their future in Europe likely interpret closer ties with NATO as an enhancement of their European credentials, which contributes to the modernisation of Serbia's image following the wars of the 1990s. Petrović (2007) argues that Serbia's move toward NATO membership will depend on the "system of values at the base of the public opinion in Serbia" (p. 63), as well as those held by the political elite. Among the non-Serb population in RS, Serbia's membership of NATO might be welcomed simply because it would reduce the prospect of future conflict - converting a former enemy into an ally.

The other major factor underlying a favourable response to NATO membership and involvement in the region concerns an approach towards mutual understanding of the recent past. The data indicate that the imagined political future is closely tied to "the importance attached to agreeing a common narrative of the recent past". The more that respondents agree that Serbia would benefit from joining the NATO alliance, the more importance they attach to the people of $\mathrm{BiH}$ coming to a common understanding of the 1992-1995 war. Reaching a common understanding of the past is an important objective and the dynamics of social memory may need to be monitored, even engineered by mutual 
agreement for the education of future generations. But even though political elites may choose to "sell" a positive image of NATO to people in the region, which might increase the prospect of reconciliation in Bosnia, these developments may not be welcomed in Russia. Opinion polls in Russia continue to show relatively negative views (see Forsberg, 2005 for an extended discussion of Russia's relationship with NATO). Indeed, Russia has continually expressed objections to NATO expansion into Eastern Europe (see Rühle, 2014) and we must bear in mind that the desire to forge political and economic links with the EU was a precipitating factor in the current conflict in the Ukraine.

Future research, nonetheless, needs to address the sizeable minority support for NATO membership among the Serb population of RS. How may this be explained or understood? Are there additional social and/or political factors that characterise this group that have yet to be identified? There also needs to be more focus on the sources that inform the views of people in the region. Which are the most trusted and why? We can only surmise the future effects of the current conflict in the Ukraine on political attitudes and affiliations in $\mathrm{BiH}$. Recent events, however, provide a clear warning that political elites and decision makers need to understand nuanced beliefs existing within specific groups if they are to manage the dynamics of political consent and explore the possibilities for political change, which is desirable for all parties within the Bosnian state.

\section{Acknowledgements}

We would like to thank all those who conducted the fieldwork for this research as well as those who participated in the study. The study was financed through a grant from NATO to the Atlantic Initiative. The views expressed here are those of the authors alone.

\section{References}

Agency for Statistics of Bosnia and Herzegovina (2013). Preliminary Results. http://www.bhas.ba/obavjestenja/Preliminari_rezultati_bos.pdf Accessed January 2014

Ansolabehere, S., Rodden, J. \& Snyder, J.M. (2006). Issue preferences and measurement error. Department of Political Science. MIT.

Ashdown, P. \& Holbrooke, R. (2008). A Bosnian powder keg. The Guardian. http://www.guardian.co.uk/commentisfree/2008/oct/22/ashdown-holbrooke-bosnia-balkandayton Accessed December 2011.

Attila Hoare, M. (2010). Bosnia-Herzegovina - the crumbling Balkan keystone. Democracy and Security in Southeastern Europe, 1, 50-55.

Azinović, V., Bassuener, K. \& Weber, B. (2011). Assessing the potential for renewed ethnic violence in Bosnia and Herzegovina: A security risk analysis. Sarajevo. Atlantic Initiative Democratization Policy Council.

Atanasović, Z. (2007). Public opinion of Serbia on joining NATO. Western Balkans Security Observer (WBSO), 5, April-June, 22-30. 
Banister, P., Burman., \& Weber, B. (2011). Assessing the potential for renewed ethnic violence in Bosnia and Herzegovina: A security risk analysis. Sarajevo. Atlantic Initiative Democratization Policy Council.

Beaumont, P. (2009). Paddy Ashdown upbeat on Bosnia's future - but wants help from US. The Guardian. http://www.guardian.co.uk/world/2009/may/03/lord-paddy-ashdown-bosnia-us Accessed November 2011.

Bećirević, E. (2009). Na Drini genocid. Sarajevo: Buy Book.

Bećirević, E. (2010). The issue of genocidal intent and denial of genocide: A case study of Bosnia and Herzegovina. East European Politics and Societies, 24, 480-502.

Bećirević, E. (2014). Genocide on the Drina River. Yale University Press: New Haven and London.

Brunborg, H., Lyngstad, T. H. \& Urdal, H. (2003). Accounting for genocide: How many were killed in Srebrenica? European Journal of Population, 19, 229-248.

Carpini, M.X.D. \& Keeter, S. (1993). Measuring political knowledge: Putting first things first. American Journal of Political Science, 37, 1179-1206.

Crabtree, M., \& Miller, W. (Eds.). (1999). Doing qualitative research. ( $2^{\text {nd }}$ ed.). London: Sage.

Forsberg, T. (2005). Russia's relationship with NATO: A qualitative change or old wine in new bottles? Journal of Communist Studies and Transition Politics, 21, 332-353.

Groves, R. M., Biemer, R. P., Lyberg, L. E., Massesy, J.T., Nicholls II, W. L. \& Waksberg, J. (2001). Telephone survey methodology. New York. John Wiley \& Sons.

Hanze, M. (2001). Ambivalence, conflict, and decision making: attitudes and feelings in Germany towards NATO's military intervention in the Kosovo war. European Journal of Social Psychology, 31, 693-706.

Kleinbaum, D. G., Kupper, L. L. \& Mullet, K. E. (1988). Applied regression analysis and other multivariate methods (2nd Ed). Boston. PWS-Kent.

Klemenčič, M. (2009). The international community and the FRY/Belligerents, 1989-1997. In C. Ingrao \& T. A. Emmert (Eds.) Confronting the Yugoslav controversies: A scholars initiative (pp152-198). Washington. United States Institute of Peace Press, Indiana. Purdue University Press.

Kovács, A. (2005). NATO and Hungarian public opinion. In K. Eder,. \& W. Spohn (Eds.), Collective memory and European identity: The effects of integration and enlargement. Aldershot. Ashgate.

Nicolaas, G. (2004). Sampling Issues for Telephone Surveys in Scotland. National Centre for Social Research.

Nunnally, J.C. (1978.) Psychometric theory (2nd ed). New York. McGraw Hill.

Peduzzi P., Concato J., Kemper E., Holford T.R., \& Feinstein A. R. (1996). A simulation study of the number of events per variable in logistic regression analysis. Journal of Clinical Epidemiology, 49, 1373-1379. 
Petrovic, J. (2007). Foreign Policy aspects of the Republic of Serbia's accession to NATO. Western Balkans Security Observer, (WBSO), 5, April-June, 55-63.

Radeva, B. (2010). A roadmap for the alliance; a roadmap for the region. Democracy and Security in Southeastern Europe, 1, 2/3, 28-31.

Ramet, S.R. (2005). Thinking about Yugoslavia. Cambridge: Cambridge University Press.

Republika Srpska Insitute of Statistics (2009). Republika Srpska in figures. Banja Luca.

Roberts, R., Bećirević, E., \& Paul, S. (2011). Truth and denial: Psychological perspectives on reconciliation in Bosnia. In R. J. Elford (Ed.), Just reconciliation: The practice and morality of making peace. (pp. 129-146). Oxford: Peter Lang.

Ruhle, M. (2014). NATO enlargement and Russia: Myths and realities. NATO Review. htpp://www.nato.int/docu/review/2014/Russia-ukraine-nato-crisis/nato-enlargement-russia/en/index.htm Accessed Feb 2015.

Šolaya, M. (2010). Between conditionality and membership. Democracy and Security in Southeastern Europe, 1, 1, 69-74.

State Agency for Statistics for BiH (2001). Bosnia-Herzegovina Living Standadrds Measurement Study survey. microdata.worldbank.org/index.php/catalog/65/download/11424. Accessed November 2011.

Stokes, G. (2009). Independence and the fate of minorities, 1991-1992. In C. Ingrao \& T. A. Emmert (Eds.), Confronting the Yugoslav controversies: A scholar's initiative (pp. 82-112). Washington. United States Institute of Peace Press, Indiana: Purdue University Press.

Streiner, D. L. \& Norman, G. R. (1989). Health measurement scales: A practical guide to their development and use. Oxford: Oxford University Press.

Vittinghoff, E. \& McCulloch, C. E. (2006). Relaxing the rules of ten events per variable in logistic and Cox regression. American Journal of Epidemiology, 165 (6), 710-718.

Ziegler, A. H. (1987). The structure of Western European Attitudes toward Atlantic Co-operation: Implications for the Western Alliance. British Journal of Political Science, 17, 457-477.

\section{List of Tables and Figures}

\section{Tables}

1a. Responses to questionnaire statements regarding attitudes to NATO

1b. Responses to questionnaire statements regarding political attitudes 
2a. Logistic Regression: predicting favourable/unfavourable attitudes to NATO amongst Serbs $(\mathrm{N}=807)$

2b. Logistic Regression: predicting favourable/unfavourable attitudes to NATO amongst NonSerbs $(\mathrm{N}=41)$

\section{Figures}

1. Distribution of Scores for composite variable: Attitude to NATO (scores above the midpoint, 36 denote a favourable attitude , and scores below 36 an unfavourable view).

2. Mean Attitude to NATO by Age Group (95\% confidence intervals shown).

3. Mean Attitude to NATO by Ethnicity (95\% confidence intervals shown).

4. Predicting NATO scale scores: Distribution of results generated from 110 trials using artificial neural network (MLP) analysis. Model as described in the text.

5. Actual NATO scores compared with predicted results from a typical MLP analysis. 


\section{Table1a. Responses to questionnaire statements regarding attitudes to NATO}

\begin{tabular}{|c|c|c|c|c|c|c|}
\hline & \multicolumn{2}{|l|}{ Whole Sample } & \multicolumn{2}{|l|}{ Serb } & \multicolumn{2}{|l|}{ Non-Serb } \\
\hline & Agree & Disagree & Agree & Disagree & Agree & Disagree \\
\hline NATO Membership: & & & & & & \\
\hline is a good thing for RS & $155(16.3 \%)$ & $647(68.1 \%)$ & $133(14.8 \%)$ & $630(70.4 \%)$ & $22(44.0 \%)$ & $13(26.0 \%)^{* *}$ \\
\hline will enhance security in RS & $165(17.3 \%)$ & $629(66.2 \%)$ & $141(15.7 \%)$ & $612(68.4 \%)$ & $24(50.0 \%)$ & $13(26.0 \%)^{* *}$ \\
\hline will bring economic benefits to RS & $164(17.3 \%)$ & $607(63.9 \%)$ & $143(16.0 \%)$ & $592(66.1 \%)$ & $21(42.0 \%)$ & $12(24.0 \%)^{* *}$ \\
\hline will enhance international reputation of RS & $241(25.3 \%)$ & $500(52.6 \%)$ & $214(23.9 \%)$ & $486(54.3 \%)$ & $27(54.0 \%)$ & $10(20.0 \%)^{* *}$ \\
\hline will strengthen democracy in RS & $113(11.9 \%)$ & $626(65.9 \%)$ & $96(10.7 \%)$ & $606(67.8 \%)$ & $17(34.0 \%)$ & $16(32.0 \%)^{* *}$ \\
\hline will improve BiH's chances for EU accession & $365(38.4 \%)$ & $363(38.2 \%)$ & $327(36.5 \%)$ & $359(40.1 \%)$ & $37(74.0 \%)$ & $13(26.0 \%)^{* *}$ \\
\hline would be a good thing for $\mathrm{BiH}$ & $189(19.8 \%)$ & $582(61.3 \%)$ & $155(17.3 \%)$ & $571(63.8 \%)$ & $33(66.0 \%)$ & $9(18.0 \%)^{* *}$ \\
\hline $\begin{array}{l}\text { will contribute to good relations with other countries } \\
\text { in the region }\end{array}$ & $218(22.9 \%)$ & $484(50.9 \%)$ & $190(21.2 \%)$ & $473(52.9 \%)$ & $27(54.0 \%)$ & $8(16.0 \%)^{* *}$ \\
\hline NATO expansion is a bad thing & $633(66.9 \%)$ & $123(13.0 \%)$ & $619(69.2 \%)$ & $98(11.0 \%)$ & $10(20.0 \%)$ & $25(50.0 \%)^{* *}$ \\
\hline NATO has made this region more unstable & $664(69.9 \%)$ & $93(9.8 \%)$ & $652(72.8 \%)$ & $69(7.7 \%)$ & $9(18.0 \%)$ & $23(46.0 \%)^{* *}$ \\
\hline I believe that $\mathrm{BiH}$ will join NATO in the next 5 years & $188(19.8 \%)$ & $431(45.4 \%)$ & $166(18.5 \%)$ & $419(46.8 \%)$ & $21(42.0 \%)$ & $11(22.0 \%)^{* *}$ \\
\hline NATO has outlived its purpose in the world & $482(50.8 \%)$ & $135(14.2 \%)$ & $470(52.5 \%)$ & $116(12.9 \%)$ & $8(16.0 \%)$ & $19(38.0 \%)^{* *}$ \\
\hline
\end{tabular}




\section{Table.1b Responses to questionnaire statements regarding political attitudes}

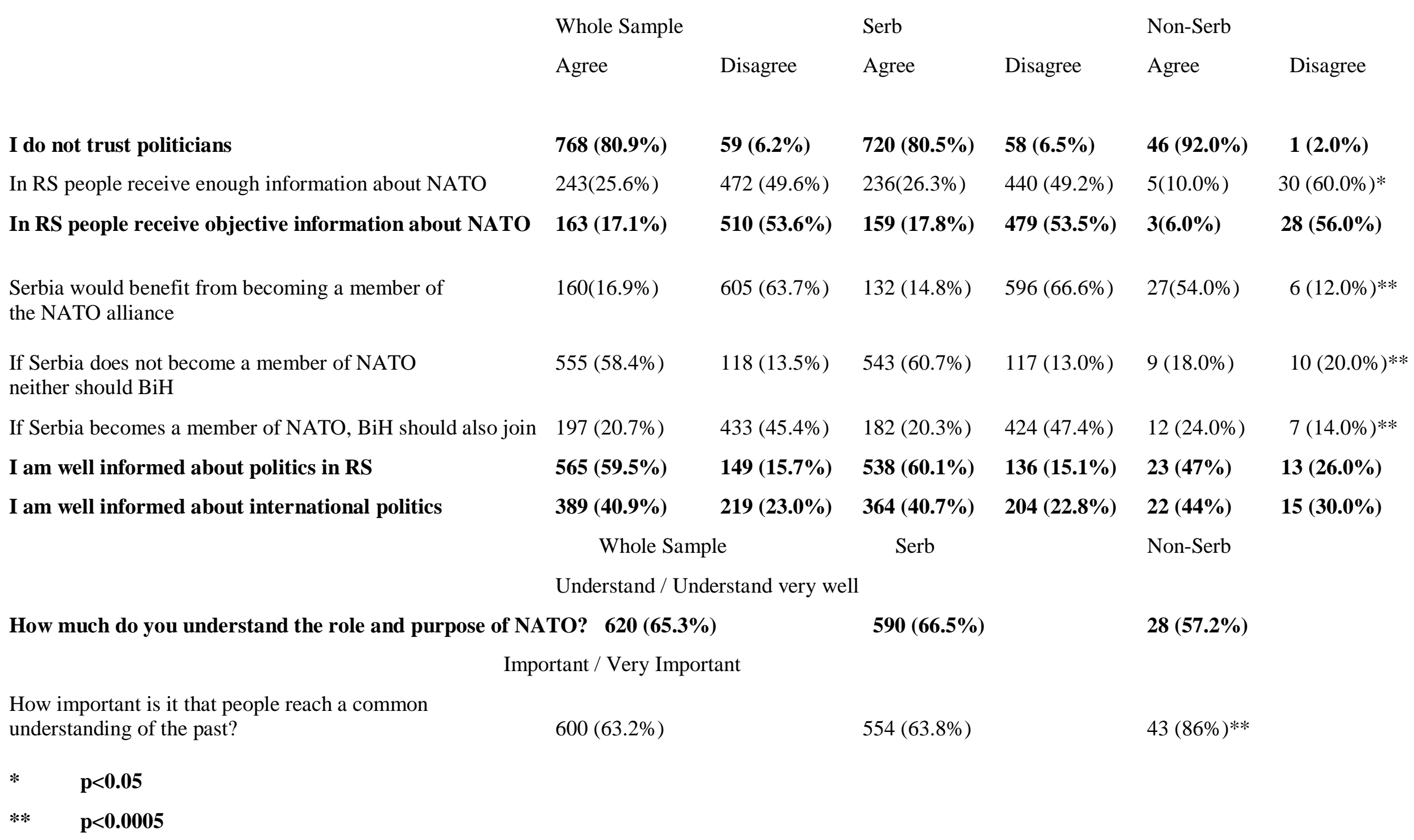


Table.2a Logistic Regression: predicting favourable/unfavourable attitudes to NATO amongst Serbs (N=807)

\section{\% Correct Classification}

Step 1

$80.2 \%(2.5 \%, 99.8 \%)$

$\operatorname{Age}^{*}(\mathrm{p}=0.04)$, Education $(\mathrm{p}=0.12)$, Gender* $\left.^{*} \mathrm{p}=0.03\right)$

Step 2

$80.4 \%(16.0 \%, 96.7 \%)$

103.74(16), $\mathrm{p}<0.0005$

Age $(p=0.06)$, Education $(p=0.12)$, Gender $(p=0.64)$

Distrust politicians $(\mathrm{p}<0.0005)$, Informed about politics in $\mathrm{RS}(\mathrm{p}=0.49)$

Informed about politics internationally $(\mathrm{p}=0.95)$, Understand the role and purpose of NATO** $(\mathrm{p}<0.0005)$

Understanding the past** $(\mathrm{p}<0.0005)$

Step 3

$89.1 \%(69.3 \%, 94.1 \%)$

$412.65(17), \mathrm{p}<0.0005$

5.99 (8), $\mathrm{p}=0.65$

$40.0 \%-64.8 \%$
Hosmer \& Lemeshow $\chi^{2}$

3.24 (7), $\mathrm{p}=0.86$

$6.25(8), p=0.62$
$12.1-19.0 \%$

Age $(\mathrm{p}=0.17)$, Education $(\mathrm{p}=0.18)$, Gender $(\mathrm{p}=0.91)$

Distrust politicians ( $p=0.87$ ), Informed about politics in $\mathrm{RS}(\mathrm{p}=0.34)$

Informed about politics internationally $(\mathrm{p}=0.49)$, Understand the role and purpose of NATO* $(\mathrm{p}=0.04)$

Understand the past** $(\mathrm{p}<0.0005)$

Serbia would benefit from NATO membership** $(\mathrm{p}<0.0005)$

* $\quad \mathbf{p}<0.05$

** $\quad \mathbf{p}<\mathbf{0 . 0 0 0 5}$ 
Table.2b Logistic Regression: predicting favourable/unfavourable attitudes to NATO amongst Non-Serbs (N=41)

\section{\% Correct Classification}

$70.7 \%(90.0 \%, 18.2 \%)$

Age $(\mathrm{p}=0.53)$, Gender $(\mathrm{p}=0.35)$

Step $2 \quad 75.6 \%(90.0 \%, 36.4 \%)$

Age $(p=0.42)$, Gender $(p=0.37)$

Understand the role and purpose of NATO* $(\mathrm{p}=0.08)$

Understand the past $(\mathrm{p}=0.13$ )

Step 3

$80.5 \%(86.7 \%, 63.6 \%)$

\section{Model $\chi^{2}$}

$9.38(6), p=0.15$

$15.39(8), p=0.05$

$22.01(9), p=0.009$
Hosmer \& Lemeshow $\chi^{2}$

4.22 (5), $\mathrm{p}=0.52$

$1.62(7), p=0.98$

$31.3 \%-45.5 \%$
Pseudo $\mathbf{R}^{2}$

$20.5 \%-29.8 \%$

Age $(p=0.59)$, Gender $(p=0.34)$

Understand the role and purpose of NATO $(\mathrm{p}=0.68)$

Understand the past $(\mathrm{p}=0.78$ )

Serbia would benefit from NATO membership* $(p=0.08)$

* $\quad \mathbf{p}<\mathbf{0 . 0 1}$ 


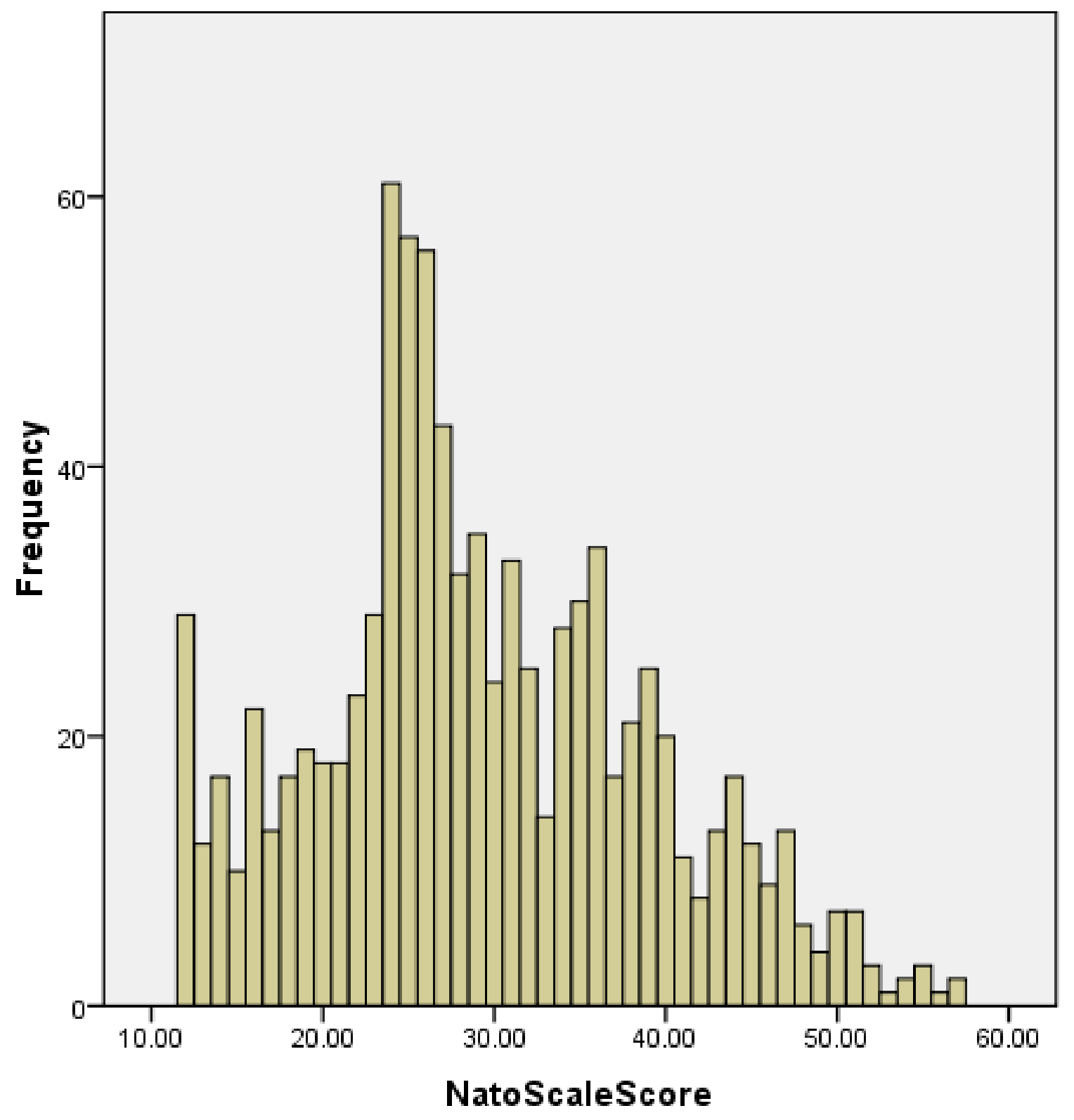

Figure 1. Distribution of scores for composite variable: Attitude to NATO (scores above the midpoint 36 denote a favourable attitude and scores below 36 an unfavourable view) 


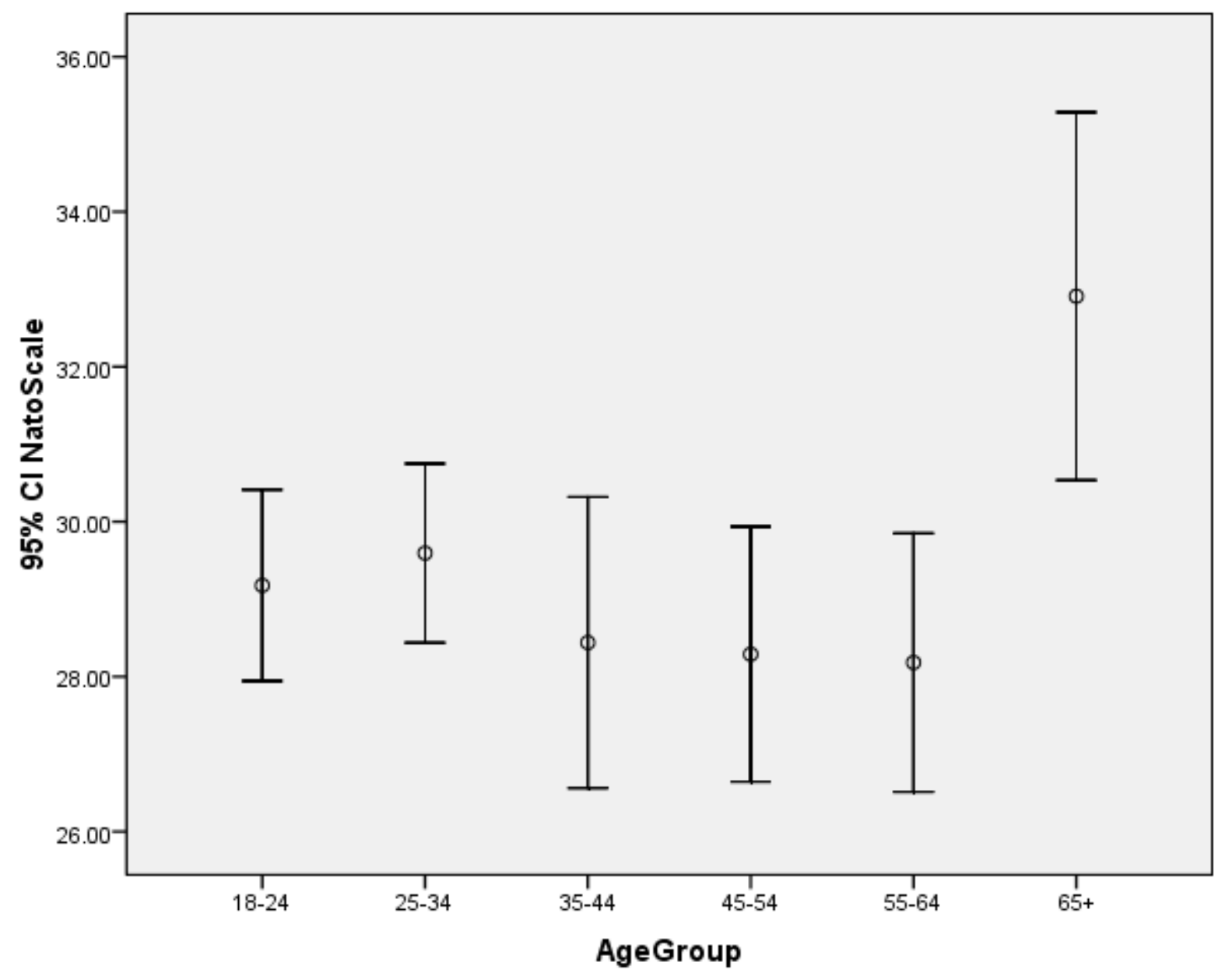

Figure 2. Mean Attitude to NATO by Age Group (95\% confidence intervals shown) 


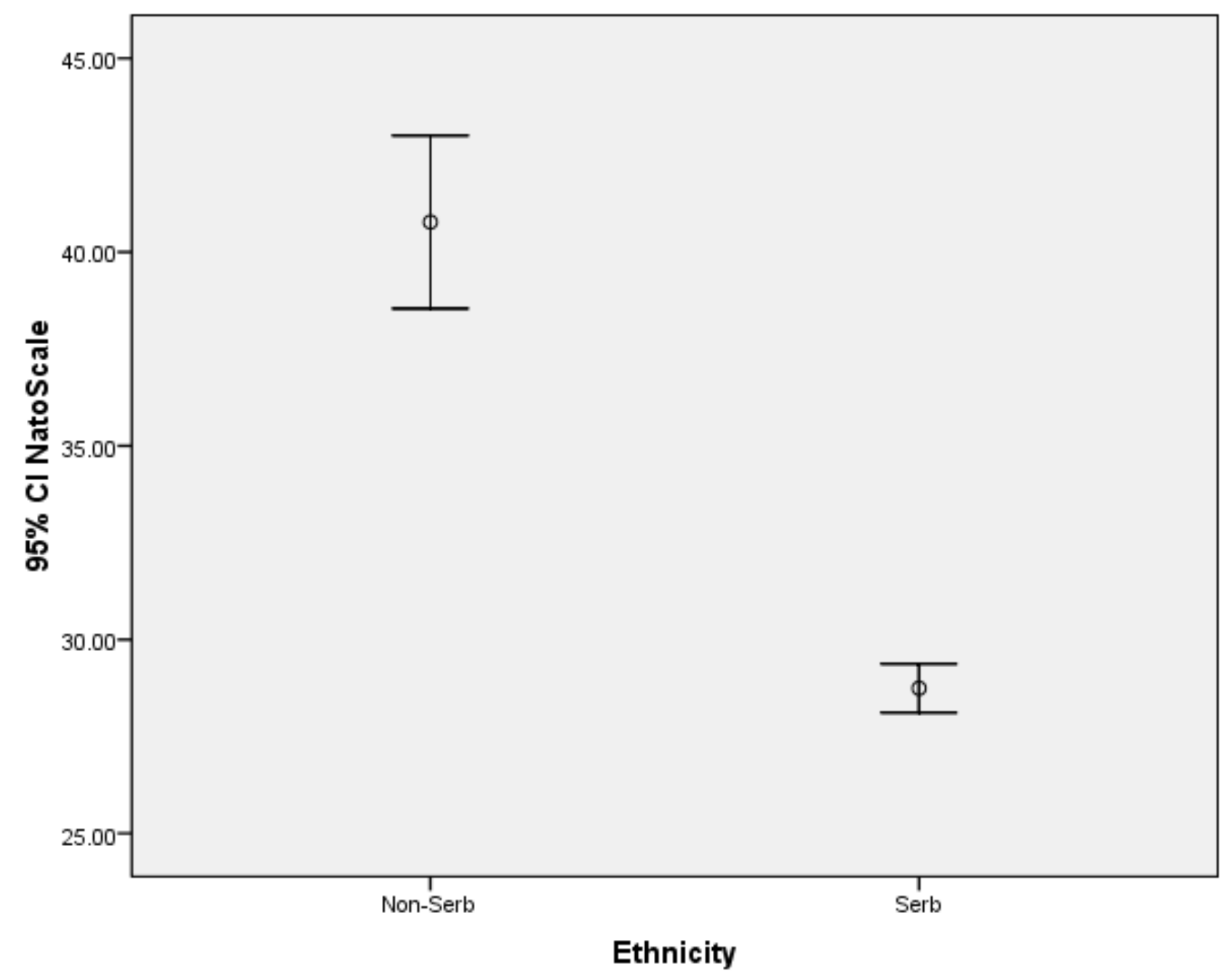

Figure 3. Mean Attitude to NATO by Ethnicity (95\% confidence intervals shown) 


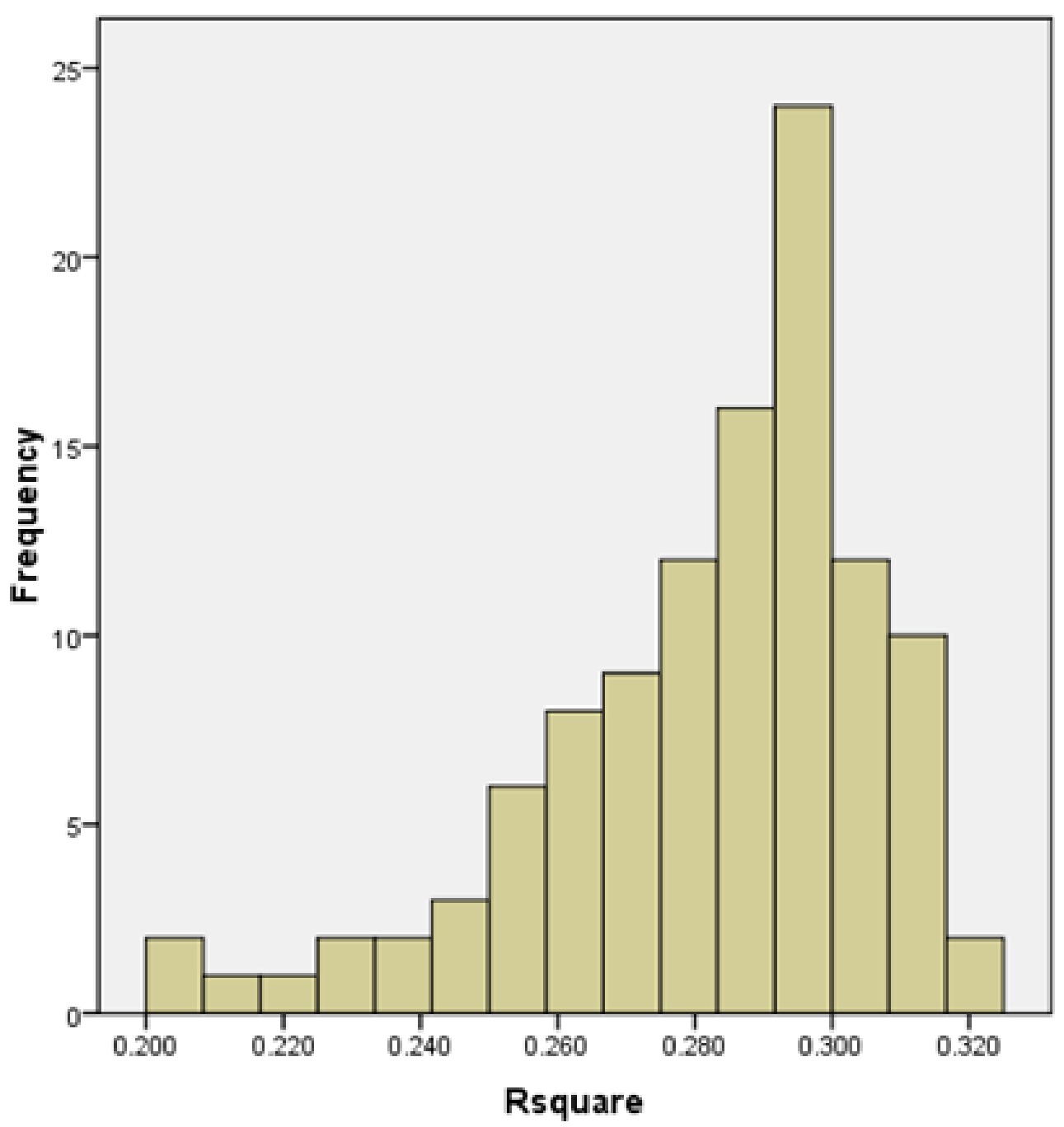

Figure 4. Predicting NATO scale scores: Distribution of results generated from 110 trials using artificial neural network (MLP) analysis. Model as described in the text 


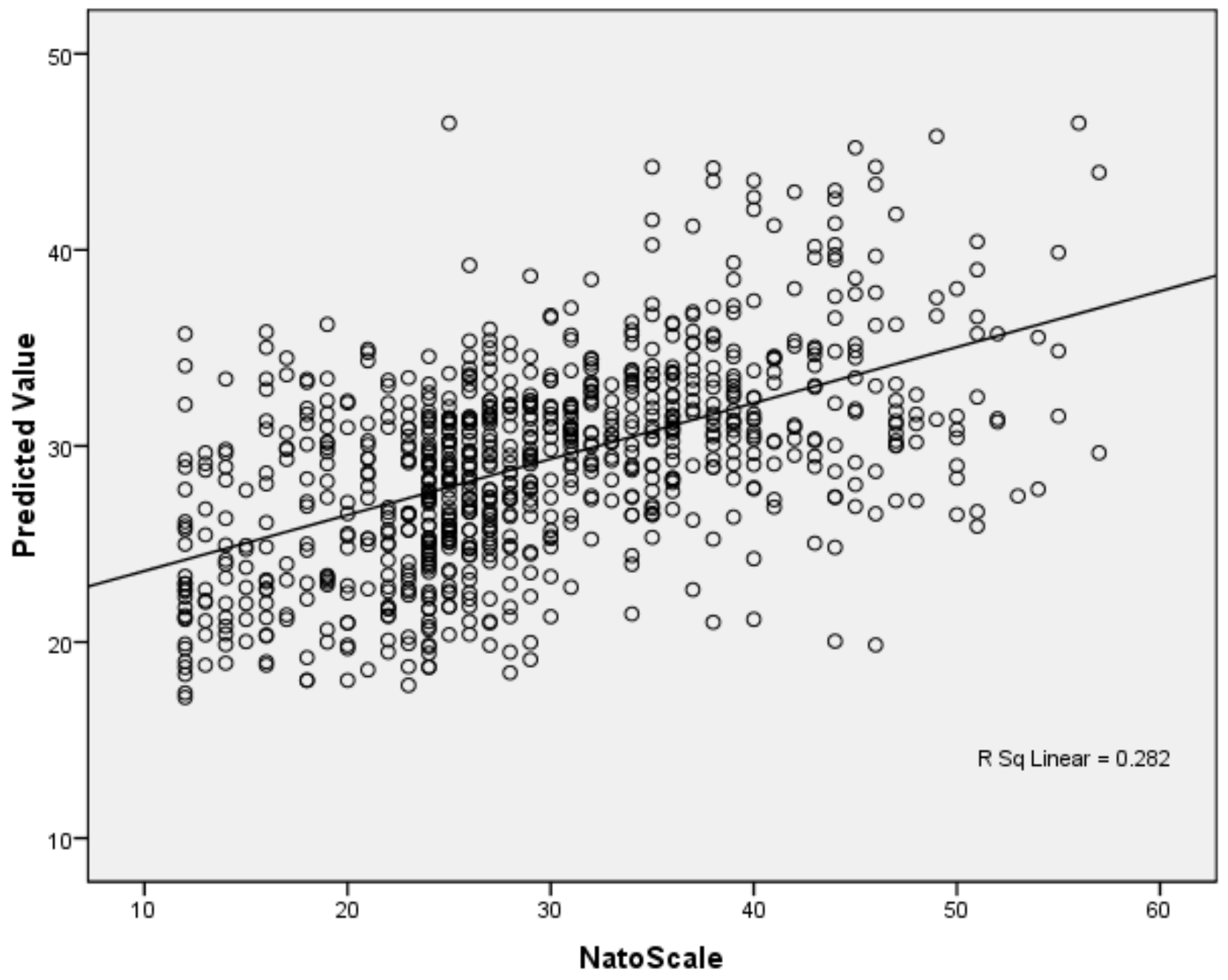

Figure 5. Actual NATO scores compared with predicted results from a typical MLP analysis 